\title{
PENGARUH KINERJA LINGKUNGAN DAN CORPORATE SOCIAL RESPONSIBILITY DISCLOSURE PADA KINERJA KEUANGAN PERUSAHAAN SEKTOR PERTAMBANGAN
}

\author{
Yohanes Made Supadi ${ }^{1}$ \\ I Putu Sudana 2 \\ ${ }^{1}$ Fakultas Ekonomi dan Bisnis Universitas Udayana, Bali, Indonesia \\ ${ }^{2}$ Fakultas Ekonomi dan Bisnis Universitas Udayana, Bali, Indonesia \\ Email: yohanesmade.supadi@gmail.com
}

\begin{abstract}
ABSTRAK
Tujuan dari penelitian ini adalah untuk mengkaji pengaruh kinerja lingkungan dan CSR Disclosure pada kinerja keuangan perusahaan sektor pertambangan yang terdaftar di Bursa Efek Indonesia. Sampel ditentukan dengan teknik purposive sampling, dan diperoleh 10 perusahaan sebagai sampel dengan 30 amatan. Data yang terkumpul dianalisis dengan uji regresi linear berganda. Hasil penelitian menunjukkan Kinerja Lingkungan bepengaruh positif pada Kinerja Keuangan perusahaan. Temuan ini menunjukkan bahwa keberadaan suatu perusahaan akan terlegitimasi manakala terdapat keselarasan antara nilai yang dicapai perusahaan dengan ekspektasi masyarakat dalam lingkungan sosial perusahaan. Kinerja lingkungan mampu menaikkan citra perusahaan melalui peningkatan kinerja keuangan perusahaan. Temuan lainnya adalah bahwa CSR Disclosure berpengaruh positif pada Kinerja Keuangan perusahaan, yang menunjukkan bahwa CSR merupakan wujud dari bentuk perilaku transparan dan etis yang merupakan gambaran pembangunan berkelanjutan. CSR dapat digunakan sebagai strategi perusahaan untuk menjaga keberlangsungan perusahaan (going concern) dalam jangka panjang.

Kata kunci: Kinerja Lingkungan; CSR Disclosure; Kinerja Keuangan; sektor pertambangan.
\end{abstract}

\begin{abstract}
The aim of this research is to investigate the influence of environmental performance and CSR Disclosure on financial performance of mining sector companies listed in Indonesia Stock Exchange. Sample company was determined by purposive sampling technique resulting 10 sample companies with 30 observations. Data was analysised using multiple linear regression test. The result of the study shows that the environmental performance has a positive effect on companies' financial performance. These findings imply that the existence of a company will be legitimated when there is a harmony between the value achieved by the company and the expectations of society in the social environment of the company. It indicates that environmental performance is able to raise the image of the company through the improvement of the company's financial performance. Another finding shows that CSR Disclosure positively affects the companies' financial performance, implies that CSR is a form of transparent and ethical behavior that may reflect sustainable development. CSR has become the companies' strategy to keep the companies' concern in the long term.
\end{abstract}

Kata kunci: environmental performance; CSR Disclosure; financial performance; mining sector. 


\section{PENDAHULUAN}

Pesatnya perkembangan dunia bisnis dewasa ini menuntut manajemen perusahaan untuk berupaya mengeksploitasi potensi yang dimiliki demi meningkatkan competitive advantage. Peningkatan keunggulan kompetitif dapat dicapai melalui akurasi perencanaan, pengidentifikasian kebutuhan dengan mempertimbangkan berbagai kondisi lingkungan yang selalu berubah. Kematangan perencanaan merupakan faktor penting dan terkait dengan tingkat kinerja keuangan (finance performance) perusahaan pada masa yang akan datang (Yusoff et al., 2013).

Profitabilitas dalam kinerja keuangan merupakan salah satu rasio penting untuk mengetahui hasil operasi/keuntungan suatu entitas (Lianto, 2013). Sejalan dengan pandangan Lianto, Iqbal dan Sulasmiyati (2015) mengungkapkan pentingnya rasio keuntungan ini dalam mengukur keefektifan organisasi. Return On Equity (ROE) menjadi alat pengukuran profitabilitas yang menunjukkan kemampuan perusahaan dalam menghasilkan laba bersih dengan bermodalkan ekuitas yang sudah diinvestasikan pemegang saham (Arsoy et al., 2012).

Data perusahaan tambang PT. Timah (Persero) Tbk tahun 2013 sampai 2015 menunjukan kenaikan pendapatan yang cukup signifikan yakni masing-masing Rp 5.852.453.000.000, Rp 7.371.212.000.000 dan Rp 6.874.192.000.000. Kenaikan pendapatan ini justru berbanding terbalik dengan ROE sebagai representasi kinerja manajemen dalam menghasilkan return atas modal sendiri. PT Timah (Persero) Tbk pada tahun yang sama mencatat perolehan ROE masing-masing sebesar 0,113, 0,058 dan 0,05. Kinerja keuangan perusahaan tambang ini bila 
diukur menggunakan ROE cenderung menurun meskipun pendapatan perusahaan memiliki kecenderungan positif. Hal ini diduga terdapat faktor lain selain faktor keuangan yang mempengaruhi pertumbuhan ROE yang merupakan salah satu alat ukur kinerja keuangan PT. Timah (Persero) Tbk.

Di sisi lain upaya sejumlah entitas usaha dalam memperbaiki kinerja keuangannya dengan memaksimalisasi laba menurut Ortas et al., (2015) justru memberikan dampak yang menyimpang dari kaidah-kaidah dalam masyarakat. Prinsip ini sesungguhnya mendasarkan penilaian keberhasilan finansial hanya secara tradisional yaitu dengan memfokuskan arah kebijakan pada aspek keuangan semata. Imbal hasil sebagai kontra prestasi dilihat dari pencapaian keberhasilan keuangan yang tinggi. Dalam penelitiannya Ahmed et al., (2016) menemukan bahwa perusahaan mengabaikan kepentingan-kepentingan jangka panjang ketika penilaian terhadap kinerjanya hanya semata-mata dilihat dari aspek keuangan saja. Kepentingan jangka panjang diluar aspek keuangan yang turut berpengaruh terhadap kinerja perusahaan tergambar dalam kepuasan dan loyalitas pelanggan, produk ramah lingkungan, legitimasi masyarakat dan aspek-aspek sosial lainnya yang jika diabaikan akan memunculkan ketidakstabilan pencapaian kinerja keuangan perusahaan dalam jangka panjang.

Manfaat ekonomi yang diterima menurut Pranoto dan Yusuf (2014), berdampak pada aspek sosial dan lingkungan akibat aktivitas operasi perusahaan. Industri pertambangan misalnya, menyisakan bebagai masalah lingkungan yang mengganggu kehidupan masyarakat disekitarnya. Kerusakan lingkungan ditimbulkan karena buangan limbah tambang yang mengandung berbagai bahan 
Yohanes M. Supadi, dan I Putu Sudana. Pengaruh Kinerja Lingkungan dan ...

beracun yang mengancam habitat ekosistem. Kerusakan lingkungan ini mempengaruhi kualitas lingkungan udara, air dan tanah yang mengganggu kehidupan sosial masyarakat. Operasi industri pertambangan sebagai sektor yang paling banyak memberi dampak terhadap lingkungan, seharusnya memiliki kebijakan yang berorientasi lingkungan untuk menjamin tetap terjaganya keharmonisan kehidupan sosial dan lingkungan dimana perusahaan beroperasi. (Burhany, 2014). Kerusakan lingkungan akibat operasi tambang menyebakan perusahaan kehilangan legitimasi sosial dan harus menanggung biaya perbaikan terhadap lingkungan dan biaya sosial yang menggeruk profitabilitas perusahaan dan pada gilirannya mempengaruhi kinerja keuangan perusahaan dalam jangka panjang.

Persoalan lingkungan akibat penambangan dapat ditunjukan oleh data yang memunculkan konflik sosial. Tahun 2014 suatu organisasi pencinta lingkungan mempublikasikan hasil investigasinya terhadap aktivitas tambang batubara di Provinsi Kalimantan Timur dan Kalimatan Selatan oleh PT. Indo Tambangraya Megah Tbk (ITM). Tahun 2014, perusahaan mampu menghasilkan lebih dari 29 juta ton batubara untuk pemenuhan kebutuhan dalam negeri maupun kepentingan ekspor ke sejumlah negara termasuk Thailand. Upaya mencapai target produksi ini telah mengalihfungsikan Sungai Santan sebagai sumber pemenuhan kebutuhan masyarakat menjadi lahan tambang yang mencemari air sungai yang mematikan sumber penghidupan ekonomi masyarakat setempat dengan meninggalkan lubanglubang bekas galian. Hal ini mengundang reaksi penolakan dari berbagai kalangan termasuk masyarakat dan para pemerhati lingkungan (http://www.greeners.co/). 
Keterlibatan dunia usaha dalam pembangunan berkelanjutan dibutuhkan sebagai bentuk kepedulian terhadap masyarakat di sekitarnya. Ketika perusahaan semakin berkembang, dampak terhadap kehidupan sosial dan kerusakan alam semakin tinggi. Eksploitasi alam yang tidak terkendali ini dapat mengganggu keseimbangan kehidupan (Hassan dan Harahap 2010). Pemerintah hadir melalui Kementerian Lingkungan Hidup dan Kehutanan (KLHK) untuk melindungi lingkungan dengan memantau aktivitas usaha perusahaan dalam mengekplorasi sumber daya alam. Pemantauan dilakukan melalui Program Penilaian Peringkat Kinerja Perusahaan dalam Pengelolaan Lingkungan (PROPER).

Menurut Yanti (2015) PROPER membuka informasi kepada publik mengenai tingkat kepatuhan lingkungan. Kebijakan PROPER menampilkan prestasi kerja perusahaan di bidang lingkungan hidup yang merupakan suatu bentuk tanggung jawab usaha kepada masyarakatnya. Sejalan dengan pandangan tersebut Djuitaningsih dan Ristiawati (2011) menyatakan bahwa pelestarian lingkungan oleh perusahaan merupakan wujud kepedulian terhadap lingkungan dan sosial. Perusahaan diminta untuk memberikan informasi kepada publik mengenai keberpihakannya akan lingkungannya sebagai bagian penting dalam strategi manajemen lingkungan yang ramah terhadap aspek lingkungan (Paillé et al., 2014).

Selain PROPER, terdapat pula pengukuran kepedulian sosial dan lingkungan melalui program Corporate Social Responsibility/CSR yang lebih komprehensive. Laporan keberlanjutan (Sustainability Report) adalah cara perusahaan mengungkap kegiatan CSR-nya. Konsep CSR merupakan terjemahan 
Yohanes M. Supadi, dan I Putu Sudana. Pengaruh Kinerja Lingkungan dan ...

atas salah satu startegi keberlangsungan atau sustainability perusahaan (Rasoulzadeh et al., 2013). Keberlangsungan operasional perusahaan terjadi bila entitas usaha memiliki kebijakan yang menunjukan kepeduliannnya pada dimensi sosial dan lingkungan disamping tuntutan pemegang saham atas pencapaian laba (Candrayanthi dan Saputra 2013).

Prinsip keseimbangan hubungan antara pencapaian tujuan perusahaan dan harapan masyarakat dapat dijelaskan dalam teori legitimasi. Menurut teori legitimasi (Guthrie, 2006) suatu entitas usaha beroperasi setelah mendapat persetujuan masyarakat. Persetujuan atau izin dapat dibatalkan apabila perusahaan mengingkari harapan masyarakat dengan tidak melakukan hal-hal yang diwajibkan kepadanya. Dalam hal ini Kinerja lingkungan dan CSR dipandang sebagai suatu komitmen bersama yang disetujui untuk dilaksanakan perusahaan sebagai bentuk tanggung jawabnya kepada masyarakat (Lankoski, 2000). Tujuan perusahaan untuk mencapai kinerja keuangan akan tercapai apabila perusahaan mampu menjamin diperolehnya legitimasi masyarakat (Haniffa dan Cooke, 2005).

Perusahaan pertambangan sebagai sektor bisnis yang paling memberi dampak pada aspek lingkungan dan sosial perlu menyadari bahwa kinerja lingkungan semestinya mendapat perhatian serius agar memperoleh legitimasi dari masyarakat sekitar. Legitimasi menjadi prasyarat bagi perusahaan untuk dapat diterima masyarakat. Demikian juga halnya stakeholder mempertimbangkan keputusannya dalam menanamkan modalnya melalui pertimbangan kinerja lingkungan perusahaan. Angelia dan Suryaningsih (2015) dalam penelitiannya menemukan bahwa kinerja lingkungan berpengaruh positif pada kinerja keuangan 
perusahaan. Signifikansi hubungan CSR disclosure dan kinerja keuangan juga ditunjukan oleh Yanti (2015); Kamatra dan Kartikaningdyah 2015; Nor et al., 2016 yang menemukan CSR disclosure mempunyai pengaruh pada kinerja keuangan.

Hasil penelitian berbeda ditemukan oleh Setyaningsih dan Asyik (2016) dimana kinerja lingkungan tidak mempunyai pengaruh pada kinerja keuangan. Djuitaningsih dan Ristiawati (2011) dalam penelitiannya juga menemukan hal yang sama pada perusahaan yang mengadopsi program PROPER dan CSR disclosure.

Kinerja lingkungan dan CSR Disclosure kembali diuji pengaruhnya pada kinerja keuangan dalam penelitian ini pada perusahaan sektor pertambangan. Pengukuran terhadap kinerja lingkungan menggunakan PROPER sesuai Permen Lingkungan Hidup Nomor 6 Tahun 2013 dan CSR disclosure menggunakan GRI yang dikeluarkan oleh Global Reporting Initiative. Return On Equity (ROE) menjadi proksi dalam mengukur kinerja keuangan.

Penelitian ini menguji keberadaan teori legitimasi dalam kaitannya dengan fenomena lingkungan dan keuangan yang terjadi. Temuan ini dapat dijadikan bahan masukan dan pertimbangan perusahaan untuk mengambil langkah, tindakan dan kebijakan yang tidak saja berpihak pada upaya meningkatkan laba namun juga tetap memberi perhatian terhadap dampak lingkungan dan sosial berkaitan dengan paradigma triple bottom line sebagai bagian integral dalam mempertahankan dan mengembangkan perusahaan untuk menopang pencapaian kinerja keuangan. 
Yohanes M. Supadi, dan I Putu Sudana. Pengaruh Kinerja Lingkungan dan ...

\section{TELAAH LITERATUR DAN PENGEMBANGAN HIPOTESIS}

'Kontrak sosial' menjadi dasar dibangunnya Grand Teori Legitimasi yang membingkai penelitian ini. Teori legitimasi meyakini adanya hubungan antara perusahaan dan lingkungan sosialnya. Perusahaan akan selalu berinteraksi dengan masyarakat dalam norma-norma yang berlaku sehingga kegiatan perusahaan dapat dipandang legitimate (Guthrie, 2006).

Pandangan Guthrie memberi arah kebijakan bagi perusahaan dalam upaya menyelarasan antara nilai-nilai yang melekat pada organisasi dengan normanorma perilaku yang ada dalam sistem sosial masyarakat dimana organisasi adalah bagian dari sistem tersebut. Ketidaksinkronan antara nilai dan norma tersebut akan menghadirkan ancaman terhadap legitimasi. Djuitaningsih dan Ristiawati (2011) mampu membuktikan pandangannya bahwa legitimasi mampu menhadirkan pencapaian terhadap nilai perusahaan yang meningkat ketika perusahaan berada dalam keselarasan hubungan dengan masyarakat.

Aspek kinerja lingkungan adalah bentuk kewajiban sosial perusahaan terhadap pihak eksternal dan harus menjadi bagian dari kebijakan perusahaan. Pranoto dan Yusuf (2014) menyatakan upaya perusahaan yang turut menjaga keseimbangan lingkungan yang ramah terhadap alam (green) merupakan bagian dari ukuran kepedulian lingkungan oleh perusahaan. Kepedulian ini harus menjadi aspek prioritas dalam membangun suatu sistem manajemen lingkungan yang baik dalam bentuk partisipasi kepedulian lingkungan perusahaan secara nyata dan konkrit (Andriana dan Panggabean 2017). 
Sesuai amanah Permen Lingkungan Hidup Nomor 6 Tahun 2013, kepesertaan perusahaan dalam Pogram PROPER diklasifikasikan dalam 5 peringkat kinerja PROPER sebagai berikut:

Tabel 1. Peringkat PROPER

\begin{tabular}{lcccc}
\hline $\begin{array}{c}\text { Tingkat } \\
\text { Penaatan }\end{array}$ & Peringkat & Warna & \multicolumn{2}{c}{$\begin{array}{c}\text { Efek Publikasi yang } \\
\text { Diharapkan }\end{array}$} \\
\hline Lebih dari taat & 5 & Emas & Insentif Reputasi & Penghargaan \\
& 4 & Hijau & & Stakeholder \\
Taat & 3 & Biru & & \\
Belum taat & 2 & Merah & Disinsentif & Tekanan \\
& 1 & Hitam & Reputasi & Stakeholder \\
\hline Sumber: Permen Lingkungan Hidup Nomor 6 Tahun 2013 & &
\end{tabular}

Kriteria peringkat PROPER ditampilkan dalam Tabel 2 berikut ini:

Tabel 2. Kriteria Peringkat PROPER

\begin{tabular}{|c|c|}
\hline Kode Warna & Keterangan \\
\hline Emas & $\begin{array}{l}\text { Telah secara konsisten menunjukan keunggulan lingkungan dalam proses } \\
\text { produksi atau jasa, melaksanakan bisnis yang beretika dan } \\
\text { bertanggungjawab terhadap masyarakat. }\end{array}$ \\
\hline Hijau & $\begin{array}{l}\text { Telah melakukan pengelolaan lingkungan lebih dari yang dipersyaratkan } \\
\text { dalam peraturan melalui pelaksanaan sistem pengelolaan lingkungan, } \\
\text { pemanfaatan sumber daya secara efisien melalui upaya 4R (reduce, reuse, } \\
\text { recycle, dan recovery) dan melakukan tanggungjawab sosial dengan baik. }\end{array}$ \\
\hline Biru & $\begin{array}{l}\text { Telah melakukan upaya pengelolaan lingkungan yang dipersyaratkan } \\
\text { sebagaimana diatur dalam perundang-undangan. }\end{array}$ \\
\hline Merah & $\begin{array}{l}\text { Pengelolaan lingkungan hidup tidak dilakukan dengan persyaratan } \\
\text { sebagaimana di atur dalam UU. }\end{array}$ \\
\hline Hitam & $\begin{array}{l}\text { Sengaja melakukan perbuatan atau kelalaian yang mengakibatkan } \\
\text { pencemaran atau kerusakan lingkungan atau pelanggaran terhadap } \\
\text { peraturan undang-undang atau tidak melaksanakan sanksi administrasi. }\end{array}$ \\
\hline \multicolumn{2}{|c|}{ Sumber: Permen Lingkungan Hidup Nomor 6 Tahun 2013} \\
\hline \multicolumn{2}{|c|}{ Kesadaran akan pentingnya aspek lingkungan dan sosial dalam kebijakan } \\
\hline \multicolumn{2}{|c|}{ perusahaan disamping kebijakan Pemerintah melalui sejumlah regulasi yang } \\
\hline \multicolumn{2}{|c|}{ mengatur keberpihakan pada lingkungan dan sosial telah mendorong banyak } \\
\hline \multicolumn{2}{|c|}{ perusahaan untuk mengintegrasikan pelestarian lingkungan ke dalam operasi } \\
\hline \multicolumn{2}{|c|}{ perusahaannya. Pelestarian lingkungan telah menjadi bagian dalam sustainable } \\
\hline development ya & pembangunan yang menyeimbangkan aspek ekonomi, \\
\hline
\end{tabular}


ekologi/lingkungan dan sosial. Hal ini sejalan dengan konsep triple bottom line yakni profit, planet, people atau 3P (Sahla dan Aliyah 2016). Triple bottom line adalah suatu konsep yang mendorong perusahaan agar tidak hanya mengejar profit, namun juga harus mengarahkan aktivitas usahanya untuk peningkatan hidup masyarakat (people) dan turut berperan melestarikan lingkungan (planet). Paradigma ini menghendaki para pelaku usaha untuk mengedepankan perhatian pada keberadaan sosial dan lingkungannya.

Menurut Karagiorgos (2010), pengungkapan kegiatan CSR diperlukan karena fakta bahwa perusahaan berutang tugas untuk masyarakat atau memiliki kontrak sosial. Sembiring (2005), mendefinisikan pengungkapan sebagai upaya dalam membangun komunikasi tentang dampak sosial dan lingkungan bagi kelompok rentan dalam suatu aktivitas ekonomi dan dapat bersifat mandatory atau voluntary (Nor et al., 2016). Ketentuan mengenai CSR diatur dalam Permen KLH Nomor 40 tahun 2007 tentang Tanggung Jawab Sosial dan Lingkungan Perseroan Terbatas yang pada Pasal 78 menyatakan bahwa setiap perseroan selaku subjek hukum mempunyai tanggung jawab sosial dan lingkungan.

Kriteria tentang CSR dalam dunia global digambarkan secara jelas dalam GRI. Global Reporting Initiative atau Inisiatif Pelaporan Global merupakan jejaring mandiri besar yang terdiri dari beragam pemangku kepentingan yang diluncurkan pada tahun 1997 (Sustainability Reporting Guidelines Version 3.1 tahun 2011). GRI menjadi lembaga mandiri pada tahun 2002 yang memberikan kerangka kerja pelaporan keberlanjutan yang saat ini telah digunakan oleh berbagai perusahaan di dunia. GRI telah menjadi standar dunia untuk pelaporan 
yang mengajukan prinsip dan indikator untuk mengukur kinerja ekonomi, lingkungan dan sosial perusahaan, juga standar isi laporan keberlanjutan perusahaan. Sejak tahun 2013, GRI mulai menerapkan pedoman edisi terbaru yakni G4. Walau demikian organisasi pelapor masih dibolehkan menggunakan pedoman G3.1. Laporan yang berdasarkan pedoman G3.1 akan tetap diterima sampai terbitan 31 Desember 2015 dan setelah itu harus disusun sesuai pedoman G4.

Sustainability Reporting Guidelines menawarkan dua opsi bagi suatu organisasi untuk menyusun laporan keberlanjutan yaitu Opsi Inti (Core) dan Komprehensif (Comprehensive). Opsi Inti (Core) berisi latar belakang pengungkapan dampak ekonomi, lingkungan, serta sosial dan kinerja tata kelola. Organisasi diminta untuk menyampaikan kinerjanya minimal satu indikator terkait aspek material yang teridentifikasi. Opsi Comprehensive didasarkan pada opsi inti dengan standar tambahan mengenai strategi dan analisis, tata kelola, serta etika dan integritas organisasi. Organisasi diminta menyampaikan kinerjanya dengan melaporkan semua indikator terkait aspek material teridentifikasi.

Perhatian terhadap aspek lingkungan pada akhirnya diharapkan dapat memberi dampak pada kinerja keuangan perusahaan. Sucipto (2003) menyatakan bahwa pengukuran terhadap keberhasilan suatu organisasi dalam menghasilkan laba dilakukan melalui penentuan ukuran-ukuran tertentu. Kinerja keuangan perusahaan sebagian besar diukur oleh investor dengan tingkat pengembalian investasi, harga saham atau nilai pasar dengan mengevaluasi tindakan akuntansi berdasarkan ROE. Return On Equity merupakan indikator keuangan internal 
berbasis pasar yang digunakan untuk pengambilan keputusan. Rumus untuk menghitung ROE (Murhadi, 2013:64) yaitu:

$$
\mathrm{ROE}=\frac{\text { Laba bersih setelah pajak }}{\text { Modal sendiri }} \times 100 \%
$$

Konsep penelitian yang dibangun dalam mencapai tujuan penelitian ini adalah dengan melihat keterkaitan antara konsep satu terhadap konsep lainnya dari persoalan yang diamati. Kinerja lingkungan dan CSR disclosure sebagai penyebab baru menimbulkan akibat pada kinerja keuangan setelah suatu selang waktu tertentu (lag). Hasil atau dampak dari kebijakan kinerja lingkungan dan CSR discloure tidak terjadi secara instan pada periode bersamaan tetapi memerlukan waktu untuk terjadinya efek dari kebijakan perusahaan tersebut.

\section{Pengaruh Kinerja Lingkungan pada Kinerja Keuangan}

Kinerja lingkungan merupakan suatu upaya menciptakan lingkungan yang baik guna membangun citra perusahaan di mata stakeholder dan mewujudnyatakan kepedulian terhadap lingkungan yang sejalan dengan pandangan teori legitimasi. Almilia dan Wijayanto (2007) menyatakan bahwa suatu unit usaha yang memperoleh penilaian baik dalam PROPER berpengaruh positif pada kinerja keuangan perusahaan. Restuningdiah (2010), serta Angelia dan Suryaningsih (2015) juga menemukan kinerja lingkungan mempunyai pengaruh positif pada kinerja keuangan.

Perusahaan yang memiliki strategi pengelolaan lingkungan berupa sistem manajemen lingkungan (PROPER), akan memiliki kinerja lingkungan yang baik. Kinerja lingkungan yang baik tersebut akan mendapatkan keunggulan kompetitif 
di waktu mendatang yang secara nyata meningkatkan level kinerja lingkungan mereka. Perbaikan kinerja lingkungan ini dapat mengakibatkan penghematan biaya dan meningkatkan penjualan, sehingga diharapkan memperbaiki kinerja keuangan perusahaan. oleh karena itu peneliti merumuskan hipotesis:

$\mathrm{H}_{1}$ : Kinerja lingkungan berpengaruh positif pada kinerja keuangan.

\section{Pengaruh Corporate Social Responsibility Disclosure pada Kinerja Keuangan}

Corporate Socal Responsibility disclosure berkaitan dengan usaha perusahaan memenuhi tanggung jawabnya terhadap para stakeholder baik itu untuk kepentingan internal organisasi maupun eksternal (Haslinda et al., 2016). Perusahaan yang melakukan CSR dengan baik akan mendapatkan simpati publik untuk menyenangi produknya sehingga akan meningkatkan profitabilitas perusahaan yang merepresentasikan peningkatan kinerja keuangan (Ahmed et al., 2016).

Teori legitimasi mengharuskan organisasi perusahaan menunjukkan suatu aktivitas yang stabil dalam menjaga nilai social dalam masyarakat. Kondisi ini dapat ditampilkan melalui pengungkapan (disclosure) dalam laporan keberlanjutan. Menurut Habbash (2016) organisasi dapat menggunakan disclosure untuk mendemonstrasikan perhatian manajemen akan nilai sosial, atau untuk mengarahkan kembali perhatian komunitas akan keberadaan pengaruh negatif aktivitas organisasi. Persepsi dan pengakuan publik dalam konsep teori legitimasi menurut Ahmed et al., (2016) menjadi aspek penting perusahaan dalam mengungkapkan informasi dalam laporan keuangan. 
Hubungan CSR disclosure dengan kinerja keuangan juga dapat dirujuk dalam beberapa penelitian yang telah dilakukan terdahulu. Angelia dan Suryaningsih (2015), serta Kamatra dan Kartikaningdyah (2015) membuktikan bahwa CSR disclosure berpengaruh positif pada kinerja keuangan.

Penelitian ini mengkaji sejauh mana reputasi perusahaan sebagai akibat kewajiban pengungkapan CSR-nya sebagai perusahaan yang bergerak di sektor pertambangan dalam mempengaruhi kinerja keuangannya. Peneliti menjadikan beberapa uraian tersebut di atas menjadi salah satu dasar perumusan hipotesis:

$\mathrm{H}_{2}$ : Intensitas CSR disclosure berpengaruh positif pada kinerja keuangan.

\section{METODOLOGI PENELITIAN}

Penelitian dilakukan pada perusahaan pertambangan di BEI yang mengikuti program PROPER Kementerian Lingkungan Hidup serta tersaji secara periodik dalam Sustainability Report, laporan PROPER dan annual report. Data penelitian diakses dan diunduh pada website www.idx.co.id, dan www.globalreporting.org untuk periode waktu penelitian kinerja lingkungan dan CSR disclosure tahun 2013-2015 serta tahun 2014-2016 untuk data kinerja keuangan. Periode pengamatan tersebut dimaksudkan agar memberikan gambaran mengenai intensitas pengungkapan CSR, perolehan insentif dan disinsentif kepesertaan PROPER pada ROE perusahaan.

Data dalam penelitian ini adalah data sekunder dengan populasi perusahaan publik sektor pertambangan yang berjumlah 45 perusahaan. Penentuan sampel melalui purposive sampling methode dengan kriteria perusahaan pertambangan yang telah menjadi peserta PROPER pada Kementerian Lingkungan Hidup dan 
perusahaan pertambangan yang menggunakan metode pengungkapan GRI pada CSR disclosure 2013-2015 dan dapat diakses dalam Sustainability Report (terpublikasi). Data dianalisis menggunakan regresi linear berganda.

Variabel-variabel yang dianalisis adalah variabel independen dan dependen yang didefinisikan oleh Sugiyono (2007: 59):

1) Variabel Dependen adalah variabel yang dipengaruhi atau yang menjadi akibat karena adanya variabel independen. Variabel dependen dalam penelitian ini adalah Kinerja Keuangan dan dinotasikan dengan Y. Sebagai variabel akibat, kinerja keuangan terjadi selang waktu tertentu setelah terjadinya variabel sebab yaitu kinerja lingkungan dan CSR disclosure. Pengukuran perubahan variabel Kinerja Keuangan sebagai akibat pengaruh variabel independen dalam penelitian ini diasumsikan terjadi setahun setelah variabel independen yaitu tahun 2014-2016.

2) Variabel Independen adalah variabel yang tidak terkait dan mempengaruhi variabel lain. Variabel independen dalam penelitian ini yaitu: $\mathrm{X}_{1}=$ Kinerja Lingkungan $\mathrm{X}_{2}=\mathrm{CSR}$ Disclosure. Pengukuran variabel Kinerja Lingkungan dan CSR disclosure sebagai variabel penyebab, terjadi setahun sebelum (mendahului) variabel dependen yaitu tahun 2013-2015.

\section{HASIL DAN PEMBAHASAN}

Prosedur penyampelan menghasilkan 10 perusahaan dengan 30 amatan. Perusahaan-perusahaan yang menjadi sampel adalah yang secara sukarela mengungkapkan kinerja lingkungan melalui PROPER dan kegiatan tanggung jawab sosial perusahaan dalam Sustainability Report. Opsi Core menjadi pilihan 
Yohanes M. Supadi, dan I Putu Sudana. Pengaruh Kinerja Lingkungan dan ...

yang konsisten digunakan sebagai pedoman pengungkapan CSR bagi seluruh perusahaan sampel yang dipakai dalam menyusun laporan keberlanjutannya. Opsi Core berisikan latar belakang pengungkapan oleh perusahaan berkaitan dengan dampak lingkungan, sosial dan ekonomi. Kinerja yang dilaporkan minimal memuat satu penilaian yang berhubungan dengan aspek penting teridentifikasi.

\section{Tabel 3. Hasil Statistik Deskrptif}

\begin{tabular}{lccccc}
\hline & $\mathrm{N}$ & Minimum & Maximum & Mean & Std. Deviation \\
\hline t_Kinerja_Lingkungan & 30 & 1,00 & 3,13 & 1,7674 &, 90031 \\
CSRD & 30 & 1,10 & 1,99 & 1,6738 &, 24830 \\
Kinerja_Keuangan & 30 &, 05 &, 17 &, 1127 &, 04121 \\
Valid N (listwise) & 30 & & & & \\
\hline
\end{tabular}

Sumber: Hasil Perhitungan SPSS 21

Tabel 3 memperlihatkan rata-rata kinerja lingkungan sebesar 1,7674. Hal ini menunjukan bahwa perusahaan telah menunjukan kepedulian terhadap lingkungan sebagai implementasi atas kinerja lingkungan. Performa perusahaan sektor pertambangan telah menunjukan kepedulian terhadap lingkungan. Kepedulian ini ditunjukan oleh nilai rata-rata yang berada diatas standar minimal yakni telah melakukan upaya pengelolaan lingkungan seperti disyaratkan dalam perundangundangan.

Nilai rata-rata CSR disclosure adalah sebesar 1,6738. Nilai minimum adalah 1,10 dan nilai maksimum adalah 1,99 menunjukan bahwa tingkat pengungkapan CSR dari perusahaan telah memenuhi lebih dari standar minimal pengungkapan yakni nilai 1. Merujuk pada opsi Core yang menjadi pilihan perusahaan dalam pengungkapan CSR maka setiap perusahaan seharusnya minimal memiliki nilai 1 untuk memenuhi standar umum dan standar khusus dalam pengungkapan 
CSRnya. ROE digunakan sebagai alat ukur kinerja keuangan atau profitabilitas perusahaan. Hasil penelitian menunjukan bahwa dari 30 amatan diperoleh nilai rata-rata 0,1127. Nilai ini menunjukan kinerja keuangan setiap perusahaan berdasarkan profitabilitas selama tahun pengamatan positif sebesar 0,1127 artinya dengan modal yang diinvestasikan, perusahaan mampu menghasilkan return 0,1127 dari setiap satu rupiah laba yang diperoleh.

\section{Uji Asumsi Klasik}

Uji asumsi klasik diperlukan agar diperoleh penaksir (estimator) yang BLUE (Best Linear Unbias Estimator) atau penaksir linier terbaik yang tidak bias.

\section{Uji Normalitas}

Nilai residual dari uji normalitas menunjukkan nilai $\mathrm{Z}$ Tabel=1,96 dan signifikansi diatas 0,05 . Nilai $Z$ hitung 0,983 dan signifikansi 0,288 . Oleh karena itu penelitian ini telah menggunakan data yang berdistribusi normal.

\section{Uji Heteroskedastisitas}

Heteroskedastisitas menguji apakah dalam sebuah model regresi terjadi ketidaksamaan varians residual dari satu pengamatan ke pengamatan yang lain. Hasil analisis menunjukkan nilai signifikansi pada semua variabel berada diatas 0,05 sehingga tidak terdapat heteroskedastisitas.

\section{Uji Multikolinieritas}

Uji multikolinieritas adalah suatu keadaan dimana antar variabel $\mathrm{X}$ (bebas) saling berkorelasi satu dengan yang lainnya. Batas tolerance value 0.10 dan VIF di atas 10. Jika tolerance value dibawah 0.10 atau nilai VIF diatas 10, maka dapat dipastikan telah terjadi multikolinieritas (Ghozali, 2013:105). Hasil uji 
Yohanes M. Supadi, dan I Putu Sudana. Pengaruh Kinerja Lingkungan dan ...

menunjukkan nilai VIF dibawah 10 dan Tolerance diatas 0,1 sehingga tidak terdapat multikolinieritas.

\section{Uji Autokorelasi}

Uji autokorelasi dilakukan dengan uji Durbin Watson $(D W)$ yakni jika nilai $D W$ berkisar antara nilai batas atas $\left(\mathrm{d}_{\mathrm{u}}\right)$ dan $4-\mathrm{d}_{\mathrm{u}}$ maka tidak terjadi pelanggaran autokorelasi. Hasil uji menunjukan nilai du dengan $n=30$ dan jumlah variabel independen 2 yaitu 1,5666 sehingga du dan $4-\mathrm{d}_{\mathrm{u}}$ adalah 1,5666 dan 2,4339. Oleh karena nilai $D W \quad 1,954$ berada diantara 1,5666 dan 2,4339 maka tidak ada autokorelasi.

\section{Analisis Regresi Berganda}

Hasil analisis regresi linear berganda disajikan pada Tabel 4.

Tabel 4. Hasil Uji Regresi Berganda

\begin{tabular}{|c|c|c|c|c|c|}
\hline \multirow[t]{2}{*}{ Model } & \multicolumn{2}{|c|}{$\begin{array}{c}\text { Unstandardized } \\
\text { Coefficients }\end{array}$} & \multirow{2}{*}{$\begin{array}{c}\text { Standardized } \\
\text { Coefficients } \\
\text { Beta }\end{array}$} & \multirow[t]{2}{*}{$t$} & \multirow[t]{2}{*}{ Sig. } \\
\hline & $B$ & Std. Error & & & \\
\hline (Constant) &, 166 &, 045 & & 3,670 & ,001 \\
\hline Kinerja_Lingkungan & ,022 &, 007 & ,490 & 3,209 & ,003 \\
\hline CSRD &, 056 & ,025 & ,336 & 2,198 & ,037 \\
\hline
\end{tabular}

Persamaan regresi berganda sebagai berikut:

$$
\begin{aligned}
& \hat{Y}=\alpha+\beta_{1} X_{1}+\beta_{2} X_{2}+\varepsilon \\
& Y=0,166+0,022 X_{1}+0,056 X_{2}
\end{aligned}
$$

Persamaan ini menjelaskan bahwa:

a) Konstanta sebesar 0,166 dengan tingkat signifikansi 0,001dapat dimaknai apabila variabel kinerja lingkungan $\left(\mathrm{X}_{1}\right)$ dan $C S R$ disclosure $\left(\mathrm{X}_{2}\right)$ adalah 
konstan atau masing-masing nilainya 0 (konstan) maka kinerja keuangan (Y) perusahaan memiliki nilai positif 0,166 .

b) Apabila terjadi kenaikan pada variabel kinerja lingkungan $\left(\mathrm{X}_{1}\right)$ maka variabel kinerja keuangan (Y) akan berpengaruh atau mengalami kenaikan.

c) Apabila terjadi kenaikan pada variabel kinerja lingkungan $\left(\mathrm{X}_{2}\right)$ maka variabel kinerja keuangan (Y) juga akan berpengaruh atau mengalami kenaikan.

\section{Uji Kelayakan Model}

Uji kelayakan model (Uji $\mathrm{F}$ ) digunakan untuk mengetahui tingkat signifikansi dan kemampuan model dalam menjelaskan pengaruh dari keseluruhan variabel bebas pada variabel terikat. Hasil uji menunjukan $F_{\text {hitung }}$ 8,015 dengan signifikansi 0,002 lebih kecil dari tingkat signifikansi yang telah ditetapkan $\alpha=$ $0,05(\alpha=5 \%)$. Model penelitian ini layak digunakan untuk memprediksi pengaruh kinerja lingkungan dan CSR disclosure pada kinerja keuangan.

\section{Koefisien Determinasi (R Square)}

Hasil koefisien determinasi yaitu 0,326 mengandung makna bahwa variabel kinerja lingkungan dan CSR disclosure mampu mempengaruhi kinerja keuangan sebesar 32,6\%. Sisanya 67,4\% dipengaruhi oleh variabel lain di luar model.

\section{Pengaruh Kinerja Lingkungan pada Kinerja Keuangan}

Hipotesis pertama menyatakan bahwa kinerja lingkungan berpengaruh positif pada kinerja keuangan perusahaan. Hasil uji t variabel kinerja lingkungan sebesar 3,209 dengan nilai signifikansi 0,003. Hasil ini menunjukan bahwa probabilitas signifikansi sebesar $0,003<0,05$ maka $\mathrm{H} 0$ ditolak dan $\mathrm{H}_{1}$ diterima. 
Hipotesis 1 diterima artinya terdapat pengaruh positif kinerja lingkungan pada kinerja keuangan perusahaan.

Penelitian ini menunjukan kinerja lingkungan memiliki pengaruh positif pada kinerja keuangan karena perusahaan dengan kinerja lingkungan yang baik akan mendapatkan respon yang baik dari para pemangku kepentingan dan juga berdampak pada peningkatan jangka panjang dalam pendapatan perusahaan. Hasil ini sesuai kesimpulan penelitian yang dilakukan Angelia dan Suryaningsih (2015), Rasoulzadeh et al., (2013), dan Nor et al., (2016).

Penelitian ini memberikan kontribusi bagi implikasi teoritis. Teori legitimasi menjadi faktor penting pengaturan hubungan dalam bentuk kontrak sosial antara perusahaan dan masyarakat untuk menyelaraskan nilai perusahaan dan nilai sosial. Temuan ini dapat dijadikan dasar untuk memperkuat keberadaan teori legitimasi yaitu bagaimana memasukkan kepentingan publik dalam strategi perusahaan. Keberadaan teori legitimasi mampu mengatasi perbedaan kepentingan antara perusahaan dan masyarakat yang pada akhirnya dapat memaksimalkan nilai perusahaan secara keseluruhan dan sekaligus memaksimalkan nilai sosial itu sendiri.

Implikasi kebijakan dalam penelitian ini berupa solusi bagi perusahaan untuk mengatasi permasalahan kinerja keuangan yakni dengan memperbaiki kinerja lingkungan perusahaan. Perbaikan terhadap efek penambangan dapat memberikan peningkatan yang signifikan bagi profitabilitas. Oleh karena itu manajemen perlu untuk mengevaluasi kinerja lingkungannya. Evaluasi terhadap kinerja lingkungan penting karena merupakan suatu proses untuk memfasilitasi 
keputusan manajemen mengenai kinerja lingkungan organisasi dengan memilih indikator dan menilai informasi terhadap kriteria kinerja lingkungan. Evalusi berkala diharapkan dapat mendorong perusahaan mencapai environmental excellency melalui integrasi prinsip-prinsip pembangunan berkelanjutan dalam proses produksi dan jasa, penerapan sistem manajemen lingkungan, 3R (Reuse, Reduce, Recycle) dalam penanganan limbah, efisiensi energi, konservasi sumber daya dan pelaksanaan bisnis yang beretika. Perusahaan perlu mengutamakan perlindungan lingkungan sehingga lingkungan menjadi salah satu indikator kinerja perusahaan.

Kinerja lingkungan merupakan program yang efektif dalam membina dan mendorong tingkat penaatan perusahaan dalam pengelolaan lingkungan serta menjadikan isu lingkungan sebagai salah satu pendorong inovasi dan peningkatan daya saing perusahaan. Perusahaan senantiasa berusaha efektif dan seefisien mungkin dalam menjalankan kegiatan usahanya. Oleh karena itu perusahaan perlu mendapatkan legitimasi dari masyarakat. Legitimasi timbul apabila terjadi kesesuaian antara pengharapan masyarakat dengan operasional perusahaan. Jika perusahaan telah mendapatkan legitimasi masyarakat maka perusahaan akan mendapatkan image positif yang akan meningkatkan kinerja perusahaan.

\section{Pengaruh CSR Disclosure pada Kinerja Keuangan}

CSR disclosure yang dilaporkan perusahaan sektor pertambangan yang terdaftar di BEI berpengaruh pada kinerja keuangan perusahaan pada tahun penelitian. Perusahaan yang telah melakukan CSR dan melaporkannya dalam Sustainability Report mampu menarik simpati masyarakat yang berdampak pada 
peningkatan profitabilitasnya. Implementasi CSR melalui pengungkapan sektor ekonomi, lingkungan dan sosial mampu menarik perhatian stakeholder bagi peningkatan kinerja keuangan.

Temuan ini sejalan dengan penelitian Angelia dan Suryaningsih (2015), Kamatra dan Kartikaningdyah (2015) bahwa CSR disclosure yang dipublikasi oleh perusahaan berpengaruh pada financial performance perusahaan. Pengungkapan CSR menjadi sarana komunikasi perusahaan kepada stkaeholder yang mampu menaikan tingkat profitabilitas.

Penggunaan variabel CSR disclosure dalam penelitian ini memberikan implikasi positif bagi teori legitimasi. Hasil penelitian menunjukan bahwa hadirnya variabel CSR disclosure pada model penelitian ini, efektif untuk menjelaskan peran teori legitimasi yang mampu mempengaruhi kinerja keuangan. Fenomena lingkungan yang terjadi pada lingkungan perusahaan pertambangan memperkuat peran teori legitimasi dalam menyeimbangkan berbagai kepentingan perusahaan dan sosial. Teori legitimasi merupakan teori yang menginterpretasikan bagaimana dan mengapa suatu korporasi peduli dengan isu lingkungan. Perspektif sistem yang dibangun melalui teori legitimasi mengasumsikan bahwa perusahaan dipengaruhi oleh masyarakat dan pada gilirannya perusahaan yang mempengaruhi masyarakat tempat perusahaan beroperasi. Tujuan perusahaan menurut teori legitimasi adalah untuk melegitimasi perilakunya dengan mengelola persepsi masyarakat.

Hasil penelitian ini memberi ruang bagi perusahaan untuk mengelola persepsi masyarakat sebagai implikasi kebijakan penelitian ini. Kegiatan bisnis 
yang dijalankan perlu mempertimbangkan dampak positif pada lingkungan untuk mewujudkan keberlanjutan. Perusahaan perlu mempertimbangkan pengelolaan dampak lingkungan dan sosial melalui inovasi-inovasi kinerja secara menyeluruh mulai dari perencanaan tambang sampai dengan pascatambang. Program-program CSR yang dilaksanakan dititikberatkan pada pemberdayaan untuk menciptakan kemandirian masyarakat dengan berbasiskan sumber daya lokal, mendukung program pendidikan berbasis lingkungan yang dikembangkan oleh pemerintah, menjalin kemitraan untuk pengembangan produksi serta meningkatkan efisiensi untuk meningkatkan daya saing produk. Kegiatan-kegiatan pengembangan masyarakat dan program kemitraan dan bina lingkungan secara berkesinambungan akan mampu meminimalisasi dampak operasi perusahaan. Pengungkapan CSR Disclosure dapat menjadi key performance indicator untuk penerapan ekonomi hijau yakni kepedulian terhadap People, Planet dan Profit melalui penyediaan alokasi dana community development. Hal ini merupakan strategi perusahaan dalam menjaga keberlangsungan perusahaan (going concern) dalam jangka panjang pasca pengungkapan.

Keberadaan suatu perusahaan dipengaruhi oleh dukungan stakeholder. Stakeholder dapat mengendalikan pemakaian sumber-sumber ekonomi yang digunakan perusahaan. Power stakeholder ditentukan besar kecilnya power yang dimiliki stakeholder atas sumber tersebut. Power tersebut berupa kemampuan untuk membatasi pemakaian sumber ekonomi yang terbatas (modal dan tenaga kerja), akses terhadap media, kemampuan mengatur perusahaan, atau kemampuan mempengaruhi konsumsi atas barang dan jasa yang dihasilkan perusahaan. 
Yohanes M. Supadi, dan I Putu Sudana. Pengaruh Kinerja Lingkungan dan ...

Pendekatan stakeholder membuat organisasi memilih untuk menanggapi banyak tuntutan dari berbagai pihak yang terkena tindakan dan keputusan manajemen.

\section{SIMPULAN DAN SARAN}

Berdasarkan hasil penelitian dan pembahasan sebelumnya, maka dapat dikemukakan kesimpulan yakni kinerja lingkungan berpengaruh positif pada kinerja keuangan. Temuan ini mampu membuktikan teori legitimasi sebagai landasan yang menjelaskan pengaruh kinerja lingkungan pada kinerja keuangan. Perusahaan harus menyelaraskan tujuan ekonomi dengan tujuan lingkungan dan sosialnya. Apabila perusahaan menginginkan kinerja keuangan perusahaan meningkat, maka perusahaan harus mampu meningkatkan kinerja lingkungannya karena masyarakat selaku konsumen akan menaruh kepercayaannya pada legitimasi tersebut.

Corporate Social Responsibility Disclosure berpengaruh positif pada kinerja keuangan perusahaan. Pengungkapan ini dipandang positif untuk dilaksanakan karena merupakan suatu komitmen berkelanjutan oleh dunia usaha untuk bertindak etis dan memberikan kontribusi kepada pengembangan ekonomi dari komunitas setempat ataupun masyarakat luas, bersamaan dengan peningkatan taraf hidup pekerjanya. Pengungkapan CSR berhubungan dengan pembangunan berkelanjutan, yakni bahwa suatu perusahaan dalam melaksanakan aktivitasnya harus mendasarkan keputusannya tidak semata bagi keuntungan keuangan saat ini, namun juga konsekuensi sosial dan lingkungan untuk saat ini maupun untuk jangka panjang. 
Perusahaan menjadikan pengungkapan sebagai sarana komunikasi penyampaian kinerja perusahaan secara holistik kepada masyarakat agar lebih mudah diterima dalam mendapatkan license to operate dari pemerintah dan publik. Hal ini menunjukan bahwa adanya stakeholder di luar perusahaan yang memengaruhi perusahaan telah merubah dimensi penerapan CSR. Kegiatan CSR awalnya bersifat donasi kemanusiaan, namun saat ini $C S R$ telah diterapkan oleh perusahaan agar tujuan perusahaan dalam memaksimalkan laba dan keberlanjutan perusahaan dapat terwujud. Perkembangan ini mengikuti konsep CSR yang dipengaruhi teori stakeholder. Oleh karena itu saran bagi penelitian selanjutnya diharapkan dapat menyempurnakan model penelitian ini, dengan mengadopsi teori stakeholder.

\section{REFERENSI}

Ahmed, Nma; Zakaree, S; Oladele, O. K. (2016). Corporate Social Responsibility Disclosure and Financial Performance of Listed Manufacturing Firms in Nigeria. Research Journal of Finance and Accounting, 7(4), 47-58.

Almilia, L. S., \& Wijayanto, D. (2007). Pengaruh Environmental Performance dan Environmental Disclosure terhadap Economic Performance. The 1st Accounting Conference, (November), 1-18.

Andriana, A., Rosinta., \& Panggabean, R. (2017). The Effect of Good Corporate Governance and Environmental Performance on Financial Performance of the Company (Studies on Participants of Proper Listed on Indonesia Stock Exchange). Binus Business Review, 8(81), 1-8.

Angelia, D., \& Suryaningsih, R. (2015). The Effect of Environmental Performance And Corporate Social Responsibility Disclosure Towards Financial Performance (Case Study to Manufacture, Infrastructure, And Service Companies That Listed At Indonesia Stock Exchange). Procedia - Social and Behavioral Sciences, 211, 348-355.

Arsoy, Aylin Poroy; Arabaci, O. C. (2012). Relationship: The Case Of Turkey. The Journal of Accounting and Finance, 159-176. 
Brigham, E.F. dan Houston, J. F. (2005). Dasar-dasar Manajemen Keuangan: Essentials of Financial Management. Jakarta: Salemba Empat.

Burhany, D. I. (2014). Informasi Lingkungan (Studi pada Perusahaan Pertambangan Umum yang Mengikuti PROPER Periode 2008-2009). Proceedings SNEB 2014.

Candrayanthi, A.A.A., dan I.D.G. Dharma Saputra, I.D.G.D. (2013). Pengaruh Pengungkapan Corporate Social Responsibility Terhadap Kinerja Perusahaan (Studi Empiris pada Perusahaan Pertambangan di Bursa Efek Iindonesia). EJurnal Akuntansi Universitas Udayana, 1, 141-158.

Djuitaningsih, T., \& Ristiawati, E. E. (2011). Pengaruh Kinerja Lingkungan Dan Kepemilikan Asing Terhadap Kinerja Finansial Perusahaan. Jurnal Akuntansi Universitas Jember, 9(2), 31-54.

Ghozali, I. (2013). Aplikasi Analisis Multivariate dengan Program SPSS (Edisi 7). Semarang: Badan Penerbit Universitas Diponegoro.

Guthrie, J. (2006). Legitimacy Theory: A Story of Reporting Social and Environmental Matters Within the Australian Food and Beverage Industry. Discipline of Accounting The University of Sydney Economics and Business Building (H69) The University of Sydney 2006, 1-35.

Habbash, M. (2016). Corporate governance and corporate social responsibility disclosure: evidence from Saudi Arabia. Social Responsibility Journal, 12(4), 740-754.

Haniffa, R.M. and Cooke, T. . (2005). The impact of culture and governance on corporate social reporting. Journal of Accounting and Public Policy, (September), 391-430.

Haslinda, Y., Alia D, J., \& Faizah, D. (2016). Corporate Governance and Corporate Social Responsibility Disclosures: An Emphasis on the CSR Key Dimensions. Journal of Accounting and Auditing: Research \& Practice, 2016, 114.

Hassan, A., dan Harahap, S.S. (2010). Exploring corporate social responsibility disclosure : the case of Islamic banks. International Journal of Islamic and Middle Eastern Finance and Management, Vol. 3(3), 203-227.

Iqbal, M., Hidayat, R. R., \& Sulasmiyati, S. (2015). Penilaian Kinerja Keuangan Perusahaan dengan Analisis Rasio Keuangan dan Metode Economic Value Added 
(EVA (Studi pada, PT . Jasa Marga (Persero) Tbk. dan Anak Perusahaan yang Terdaftar di Bursa Efek Indonesia Periode 2011-2014). Jurnal Administrasi Bisnis (JAB), 25(2), 1-8.

Kamatra, N., \& Kartikaningdyah, E. (2015). Effect Corporate Social Responsibility on Financial Performance. International Journal of Economics and Financial Issues, 5(2013), 157-164.

Karagiorgos, T. (2010). Corporate Social Responsibility and Financial Performance: An Empirical Analysis on Greek Companies Abstract: European Research Studies, XIII(4).

Lankoski, L. (2000). Determinants Of Environmental Profit An analysis of the firm-level relationship between environmental performance and economic performance. Helsinki University of Technology Institute of Strategy and International Business.

Lianto, D. (2013). Penilaian kinerja keuangan perusahaan menggunakan analisis du pont. Jurnal JIBEKA, 7(3), 25-31.

Mulyadi. (2007). Sistem Akuntansi. Jakarta: Salemba Empat.

Murhadi, W. R. (2013). Analisis Laporan Keuangan (1st ed.). Surabaya: Salemba Empat.

Nor, et al., (2016). The Effects of Environmental Disclosure on Financial Performance in Malaysia. Procedia Economics and Finance, 35 (October 2015), $117-126$.

Ortas, E., Álvarez, I., \& Garayar, A. (2015). The Environmental, Social, Governance, and Financial Performance Effects on Companies that Adopt the United Nations Global Compact. Journal Sustainability, 7, 1932-1956.

Paillé, P., Chen, Y., Boiral, O., \& Jin, J. (2014). The Impact of Human Resource Management on Environmental Performance: An Employee-Level Study. Journal of Business Ethics, 121(3), 451-466.

Pranoto, A. R., \& Yusuf, D. (2014). Program CSR Berbasis Pemberdayaan Masyarakat Menuju Kemandirian Ekonomi Pasca Tambang di Desa Sarijaya. Jurnal Ilmu Sosial Dan Ilmu Politik, 18, 39-50.

Rasoulzadeh, H., Hosseinipour, S. J., Ashikin, N., \& Yusof, M. (2013). Effect of Dimensions of Corporate Social Responsibility on Organization Performance. International Journal of Innovative Ideas, 13(2), 37-47.

Restuningdiah, N. (2010). Mekanisme gcg dan pengungkapan tanggung jawab 
sosial terhadap koefisien respon laba. Jurnal Keuangan Dan Perbankan, 14(3), 377-390.

Sahla, W.A; Aliyah, S. S. R. (2016). Pengungkapan Corporate Social Responsibility Berdasarkan Global Reporting Initiative ( Gri-G4 ) Pada Perbankan Indonesia. Jurnal Intekna, 16(2).

Sayekti, Y., \& Wondabio, L. S. (2007). Pengaruh CSR Disclosure Terhadap Earning Response Coefficient. Simposium Nasional Akuntansi X. Makassar, (Juli), 1-35.

Sembiring, R. E. (2005). SNA VIII Solo, 15 - 16 September 2005. In Simposium Nasional Akuntansi VIII.

Setyaningsih, R. D., \& Asyik, N. F. (2016). Pengaruh Kinerja Lingkungan Terhadap Kinerja Keuangan dengan Corporate Social Responsibility Sebagai Pemoderasi. Jurnal Ilmu Dan Riset Akuntansi, 5.

Sucipto. (2003). Penilaian Kinerja Keuangan. Universitas Sumatra Utara.

Sugiyono. (2007). Metode Penelitian Bisnis (18th ed.). Bandung: Alfabeta.

Wijayanti, R. (2011). Pengaruh Pengungkapan Sustainability Report Terhadap Kinerja Keuangan Perusahaan. Seminar Nasional Dan Syariah Paper Accountingr Nasional, 6(1).

Yanti. (2015). Pengaruh Corporate Social Responsibility Dan Environmental Performance Terhadap Kinerja Keuangan BUMN Dan Non BUMN Yang Terdaftar Di Bursa Efek Indonesia 2009-2012. Jurnal Akuntansi, XIX,(2), 242259.

Yusoff, H., Mohamad, S. S., \& Darus, F. (2013). The Influence of CSR Disclosure Structure on Corporate Financial Performance: Evidence from Stakeholders' Perspectives. Procedia Economics and Finance, 7, 213-220. 